\title{
ESTABLISHMENT OF AN IN VITRO SYSTEM FOR STUDIES ON THE INDUCED RESISTANCE OF COTTON TO XANTHOMONAS CAMPESTRIS PV. MALVACEARUM ${ }^{1}$
}

\author{
ADILSON KENJI KOBAYASHI ${ }^{2}$ and LUIZ GONZAGA ESTEVES VIEIRA ${ }^{3}$
}

\begin{abstract}
An in vitro system for studying the resistance response of cotton (Gossypium hirsutum L.) to Xanthomonas campestris pv. malvacearum was investigated. Cell suspension cultures, established from hypocotyl-derived callus of cotton cultivar 101-102B, were treated with bacterial extracellular polysaccharides (EPS) extracted from the incompatible race 18 of $X$. campestris pv. malvacearum. EPS at $600 \mu \mathrm{g} / \mathrm{mL}$ caused pronounced darkening of the suspension cultures, as indicative of cell death, 48 hours after incubation. Protein electrophoresis analysis of the time course of EPS-treated cells showed differential accumulation of several protein bands after 12-24 hours. The time course of protein accumulation and cell death was consistent with an elicitor-mediated hypersensitive response.
\end{abstract}

Index terms: Gossypium hirsutum, bacterial blight, extracellular polysaccharides, cell suspension culture, hypersensitive response.

\section{ESTABELECIMENTO DE SISTEMA IN VITRO PARA ESTUDOS DA RESISTÊNCIA INDUZIDA À XANTHOMONAS CAMPESTRIS PV. MALVACEARUM EM ALGODOEIRO}

\begin{abstract}
RESUMO - Desenvolveu-se um sistema in vitro para estudar a resistência do algodoeiro (Gossypium hirsutum L.) à Xanthomonas campestris pv. malvacearum. Foram utilizados calos originados a partir de hipocótilos da cultivar de algodoeiro 101-102B para estabelecer culturas de células em suspensão, as quais foram tratadas com polissacarídeos extracelulares bacterianos (EPS) extraídos da raça incompatível 18 de $X$. campestris pv. malvacearum. O tratamento com EPS, na concentração de $600 \mu \mathrm{g} / \mathrm{mL}$, causou acentuado escurecimento das culturas em suspensão, indicativo de morte celular, 48 horas após a incubação. A análise temporal do perfil eletroforético de proteínas extraídas das células tratadas com EPS mostrou um acúmulo diferencial de diversas proteínas após 12-24 horas. O acúmulo de proteínas e a morte celular ao longo do período estudado foram consistentes com um padrão de resposta de hipersensibilidade causada por elicitores
\end{abstract}

Termos para indexação: Gossypium hirsutum, bacteriose, polissacarídeos extracelulares, cultura de células em suspensão, hipersensibilidade.

\section{INTRODUCTION}

Plants possess a variety of inducible mechanisms to restrict the growth of invading pathogens. Recently, there has been a considerable interest in bacterial products which are responsible for triggering defense-related gene expression in plants during interactions with pathogenic bacteria, specially

\footnotetext{
1 Accepted for publication on June 11, 1999.

2 Biologist, Ph.D., Instituto Agronômico do Paraná (IAPAR), Caixa Postal 481, CEP 86001-970 Londrina, PR. Supported by CNPq. E-mail: adilson@sercomtel.com.br

3 Agronomist, Ph.D., IAPAR.
}

in incompatible interactions (Ausubel et al., 1993; Dangl et al., 1993; Palva et al., 1993; Goodman \& Novacky, 1994). Such products that may vary in their structure and composition are recognized by a given plant, inducing the expression of resistance genes and causing an increase in the synthesis of defenserelated compounds. In true incompatible interactions these events lead to the hypersensitive reaction (Atkinson, 1993; Jakobek \& Lindgren, 1993).

In some pathosystems, surface and extracellular polysaccharides of phytopathogenic bacteria have been shown to have a role in the determination of pathogenicity (Chowdhury \& Verma, 1990; Kao et al., 1992; Dow et al., 1995). In the interaction between cotton (Gossypium hirsutum L.) and 
Xanthomonas campestris pv. malvacearum, the causal agent of bacterial blight, bacterial extracellular polysaccharides (EPS) are known to contain factors determining pathogenicity, causing watersoaked lesions on susceptible and necrotic spots on resistant cotton cultivars (Borkar \& Verma, 1991).

Host responses to pathogens are very complex and difficult to interpret due to the spatial and temporal heterogeneity of defense responses in the infected tissues, as well as in the cells surrounding diseased tissues (Graham \& Graham, 1991). Defense reactions that result from pathogen attack depend on the timing and location of these individual defense responses (Dixon \& Harrison, 1990). In order to facilitate biochemical and physiological studies on induced defense reactions of plants to pathogenic organisms, several workers have successfully used cell suspension cultures instead of whole plants and replaced pathogens by their isolated compounds responsible for inducing defense responses (Ebel et al., 1984; Edwards et al., 1985; Dalkin et al., 1990; Lange et al., 1994; Wojtaszek et al., 1995; Walkes \& O’Garro, 1996).

The present investigation was undertaken to study whether cotton cell suspension cultures combined with bacterial EPS isolated from an incompatible race of $X$. campestris pv. malvacearum could reproduce the hypersensitive reaction observed in whole plants infected with the pathogen, as well as to analyze the protein accumulation as a defenserelated parameter induced in this system.

\section{MATERIAL AND METHODS}

\section{Plant material and bacterial isolate}

The plant material used in this study was excised from a cotton cultivar 101-102B (G. hirsutum), which carried the genes $\mathrm{B}_{2} \mathrm{~B}_{3}$ for resistance to $X$. campestris $\mathrm{pv}$. malvacearum. The bacterial isolate 8759 of race 18 (collected in the state of Paraná, Brazil), that is incompatible to cotton cultivar 101-102B, was used for EPS extraction.

\section{Callus induction}

Sulfuric acid-delinted seeds were surface sterilized and germinated at $28^{\circ} \mathrm{C}$ in the dark. Hypocotyl segments, approximately $1 \mathrm{~cm}$ long, from 5 day-old seedlings were cultured on solid medium containing MS salts (Murashige \&
Skoog, 1962) supplemented with $10 \mathrm{mg} / \mathrm{L}$ thiamine-HCl, $1.0 \mathrm{mg} / \mathrm{L}$ pyridoxine- $\mathrm{HCl}, 1.0 \mathrm{mg} / \mathrm{L}$ nicotinic acid, $100 \mathrm{mg} / \mathrm{L}$ myo-inositol, $0.1 \mathrm{mg} / \mathrm{L}$ kinetin, $0.1 \mathrm{mg} / \mathrm{L}$ 2,4-D and $3 \mathrm{~g} / \mathrm{L}$ Phytagel. The $\mathrm{pH}$ was adjusted to 5.8 prior to autoclaving. A filter-sterilized $(0.22 \mu \mathrm{m}$ nitrocellulose filter) glucose solution to make a $30 \mathrm{~g} / \mathrm{L}$ final concentration was added to the medium. Cultures were kept at $28^{\circ} \mathrm{C}$, under a 16 hour photoperiod $\left(30 \mu \mathrm{E} \mathrm{m}^{-2} \mathrm{~s}^{-1}\right)$ provided by cool white fluorescent lamps.

\section{Suspension culture}

Suspension cultures were established on liquid medium containing MS basal salts supplemented with $0.5 \mathrm{mg} / \mathrm{L}$ thiamine- $\mathrm{HCl}, 0.5 \mathrm{mg} / \mathrm{L}$ pyridoxine- $\mathrm{HCl}, 0.5 \mathrm{mg} / \mathrm{L}$ nicotinic acid, $100 \mathrm{mg} / \mathrm{L}$ myo-inositol, $0.5 \mathrm{mg} / \mathrm{L} 2,4-\mathrm{D}$ and $60 \mathrm{~g} / \mathrm{L}$ glucose. The $\mathrm{pH}$ was adjusted to 5.5 and the medium was filter-sterilized through a $0.22 \mu \mathrm{m}$ nitrocellulose filter. Thirty-day-old callus was transferred to $250 \mathrm{~mL}$ culture flasks containing $20 \mathrm{~mL}$ of liquid medium. Flasks were kept without shaking for approximately one week. After this period, the liquid medium including single cells or small cell aggregates were collected and transferred to a culture flask containing $30 \mathrm{~mL}$ of fresh liquid medium and placed on a gyratory shaker at $110 \mathrm{rpm}$. Cells were subcultured monthly at a ratio of 1:6 (cell suspension culture:fresh medium).

\section{Growth measurements and estimation of cell viabil-} ity

In order to determine the cell growth rate, suspension cultures were monitored by measuring the fresh weight of cells drained by centrifugation, according to Mills \& Lee (1996). Measurements were made at 5-day interval. Cell viability was monitored by staining with fluorescein diacetate (FDA) according to Widholm (1972). Aliquots of $100 \mu \mathrm{L}$ of cell suspension were withdrawn at each sampling period and the percentage of viable cells was estimated from a total of 500 cells. The values corresponded to the mean of three replicates.

\section{Isolation of bacterial extracellular polysaccharides (EPS)}

Bacterial cultures were kept on nutrient medium containing $0.5 \mathrm{~g} / \mathrm{L} \mathrm{CaNO}_{3}, 0.5 \mathrm{~g} / \mathrm{L} \mathrm{FeSO}_{4}, 2 \mathrm{~g} / \mathrm{L} \mathrm{K}_{2} \mathrm{HPO}_{4}$, $20 \mathrm{~g} / \mathrm{L}$ sucrose, $5 \mathrm{~g} / \mathrm{L}$ peptone and $20 \mathrm{~g} / \mathrm{L}$ agar. A single colony was inoculated in a 2-liter culture flask containing $500 \mathrm{~mL}$ of liquid medium composed of $1.32 \mathrm{~g} / \mathrm{L}$ $\left(\mathrm{NH}_{4}\right)_{2} \mathrm{SO}_{4}, 80 \mathrm{mg} / \mathrm{L} \mathrm{MgSO} 4,8 \mathrm{mg} / \mathrm{L} \mathrm{ZnSO}_{4}, 2.3 \mathrm{~g} / \mathrm{L}$ $\mathrm{K}_{2} \mathrm{HPO}_{4}, 12 \mathrm{~g} / \mathrm{L}$ sucrose, $2.5 \mathrm{~g} / \mathrm{L}$ casaminoacid and $1 \mathrm{~g} / \mathrm{L}$ yeast extract, and incubated at $22^{\circ} \mathrm{C}$ for 14 days on a gyratory shaker at $150 \mathrm{rpm}$. Partially purified EPS solu- 
tions were obtained following the procedure of El-Banoby \& Rudolph (1979), lyophilized, and stored at $-20^{\circ} \mathrm{C}$ until further use.

\section{EPS treatment of suspension cultured cells}

Partially purified bacterial EPS were dissolved in liquid MS medium ( $2 \mathrm{mg} / \mathrm{mL}$ for stock solution), $\mathrm{pH}$ was adjusted to 5.5 and the solution was filter-sterilized through a $0.45 \mu \mathrm{m}$ filter (Millipore). Cell suspension cultures at log phase of growth (15 days after subculture) were treated with EPS at $600 \mu \mathrm{g} / \mathrm{mL}$ final concentration. Control flasks contained liquid medium only.

\section{Total protein extraction}

Cell suspension samples were collected at $0,6,12,18$, 24 and 30 hours after EPS treatment, drained and frozen in liquid nitrogen. Cell-free culture media were stored at $-20^{\circ} \mathrm{C}$. A portion of each cell sample was accurately weighed and ground to a fine powder in pre-chilled pestle and mortar, and the resulting powder was extracted with four volumes of extraction buffer containing $62 \mathrm{mM}$ Tris- $\mathrm{HCl}$ (pH 6.8), $14 \mathrm{mM}$ ß-mercaptoethanol, 2\% sodium dodecyl sulfate (SDS) and $10 \%$ glycerol. The extracts were denatured by heating at $100^{\circ} \mathrm{C}$ for $3 \mathrm{~min}$ and centrifuged at $10,000 \mathrm{x} g$ for $10 \mathrm{~min}$ at room temperature. For extraction of proteins from culture media, samples were lyophilized and dissolved in equal volume with extraction buffer and proteins were extracted as described above.

\section{Polyacrylamide gel electrophoresis and densitomet-} ric analyses

Proteins were separated by polyacrylamide gel electrophoresis performed in $12.5 \%$ discontinuous slab gels containing SDS (Laemmli, 1970). The gels were crosslinked with $0.3 \% \mathrm{~N}, \mathrm{~N}$ 'methylenebisacrylamide at $\mathrm{pH} 8.8$, and stacking gel was made with $3.75 \%$ polyacrylamide at $\mathrm{pH}$ 6.8. Gels were stained with Coomassie Brilliant Blue R-250. Densitometric analyses of the gels were performed using a Bio-Rad video densitometer model 620 (BioRad Laboratories, Richmond, CA).

\section{RESULTS AND DISCUSSION}

For the establishment of cotton cultivar 101-102B cell suspension culture, the stationary step on liquid medium was crucial to obtain the initial inoculum. Calli subjected to shaking immediately after transference to liquid culture produced brown pigments, due to phenolic compounds oxidation, and died after few days. On the other hand, calli kept without shaking for approximately one week released single cells or small cell aggregates into the medium (Fig. 1A). Such cells were utilized as initial inoculum for the establishment of suspension culture. Cultures originated from this inoculum were constituted of a relatively homogeneous cell population (Fig. 1B) showing a linear growth rate for approximately 25 days after transferring to fresh medium. During this period fresh weight increased 5 to 7-fold (Fig. 2).

When cell suspension cultures were subjected to increasing doses of bacterial EPS, the cell viability, determined by FDA staining, was drastically reduced at concentration of $600 \mu \mathrm{g} / \mathrm{mL}$ EPS (Fig. 3). No significative decline in cell viability was

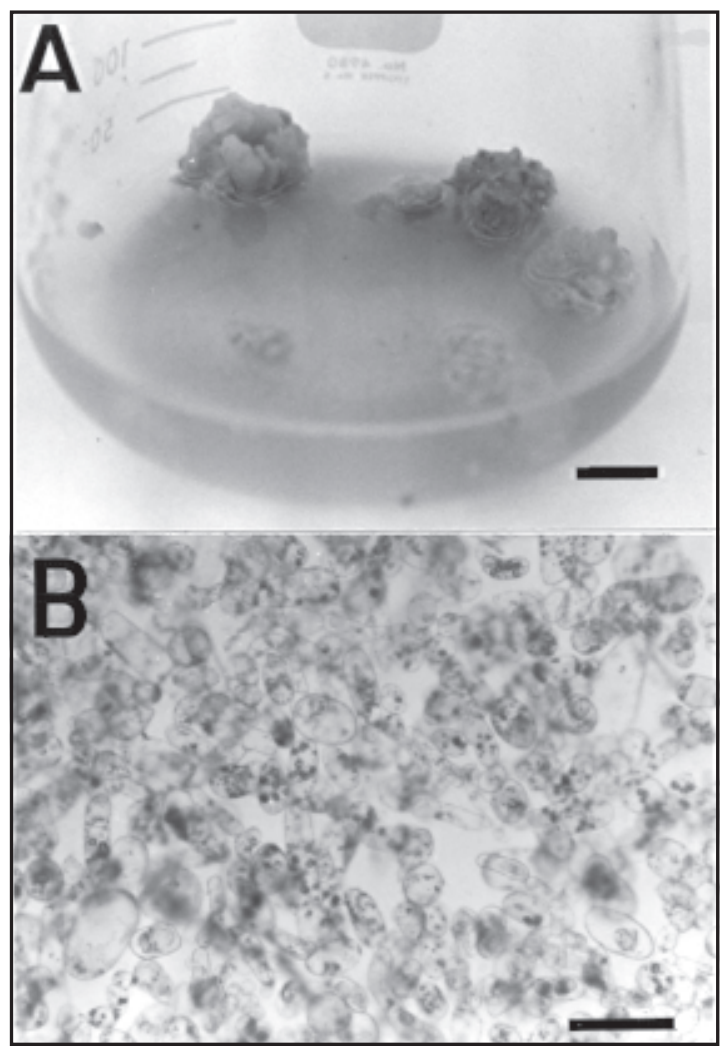

FIG. 1. Establishment of cotton cell suspension cultures. (A) Stationary liquid culture, after 1 week. Bar $=1 \mathrm{~cm}$. (B) Established cell suspension culture. $\mathrm{Bar}=100 \mu \mathrm{m}$. 
detected up to concentrations of $1,000 \mu \mathrm{g} / \mathrm{mL}$. Therefore, the subsequent investigations were conducted using EPS at $600 \mu \mathrm{g} / \mathrm{mL}$. At this EPS concentration, pronounced darkening of cell suspension cultures, indicating cell death (i.e. hypersensitive reaction), was observed after 48 hours. Keppler et al. (1988) reported that reduced plasma membrane permeability to fluorescein was associated with hypersensitive reaction in tobacco cell suspension cultures infected with incompatible Pseudomonas syringae pv. syringae.

In order to investigate whether differential accumulation of protein occurred within the cells or it was secreted to medium, electrophoresis analysis was performed separately in both drained cells and culture medium. Analysis by sodium dodecyl sulfate polyacrylamide gel electrophoresis (SDS-PAGE) of total protein extracted from cotton cell suspension cultures treated with EPS showed an accumulation of several polypeptide bands, with approximately 54, 45, 39, 36, 28, 19 and $18.5 \mathrm{Kda}$ (Fig. 4A). Although these bands were also detected in the control cells, densitometric scan-

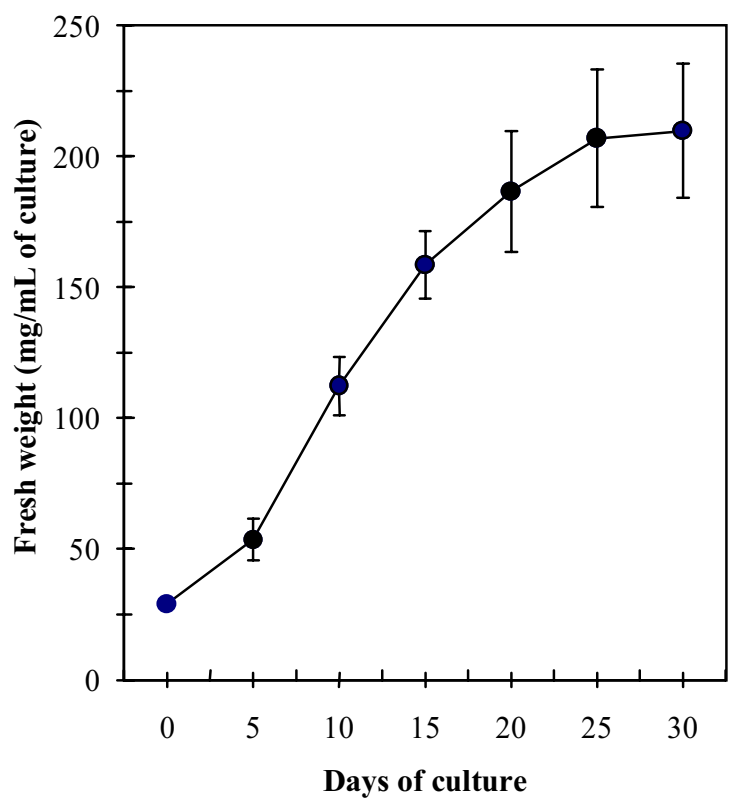

FIG. 2. Growth pattern of cotton cultivar 101-102B cell suspension culture.

Pesq. agropec. bras., Brasília, v.35, n.4, p.719-725, abr. 2000 ning of the gels showed at least 3-fold accumulation after 24 hours. Moreover, most of those polypeptide bands could be detected as soon as 12 hours after EPS treatment (Fig. 4B). Noteworthily, the $19 \mathrm{Kda}$ band showed over 15 -fold accumulation. There was also a quantitative difference in the protein secreted into the culture medium. SDS-PAGE analysis showed a decreasing pattern in the concentration of two bands (approximately 36 and $49 \mathrm{Kda}$ ) after EPS treatment (Fig. 5). Insoluble compounds, constituted of a mixture of complex carbohydrates and glycoproteins, had been detected from elicitor-treated cells in other systems (Frittensky et al., 1985; Lesney, 1989; Wojtaszek et al., 1995).

The differential accumulation of soluble proteins in plants infected by viruses, fungi and bacteria has been previously reported (Campbell \& Ellis, 1992; Popp et al., 1997). Pathogenesis-related-proteins (PR-proteins) were reported in more than $20 \mathrm{di}$ cotyledonous plants. A relationship between the accumulation of PR-proteins and disease resistance

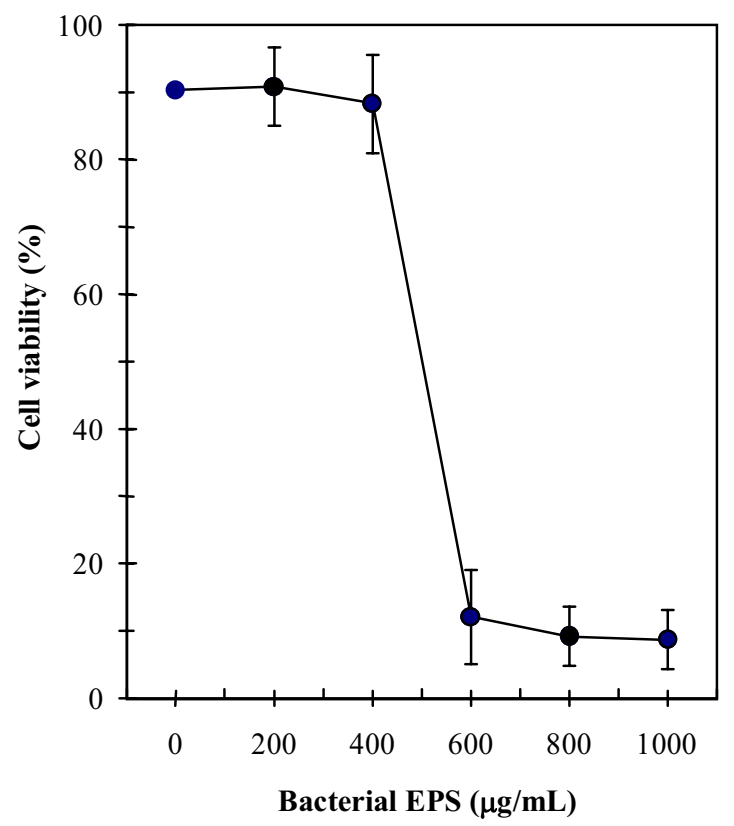

FIG. 3. Effect of increasing doses of bacterial extracellular polysaccharides (EPS) on cell viability of cotton cultivar 101-102B cell suspension cultures after 48 hours. 


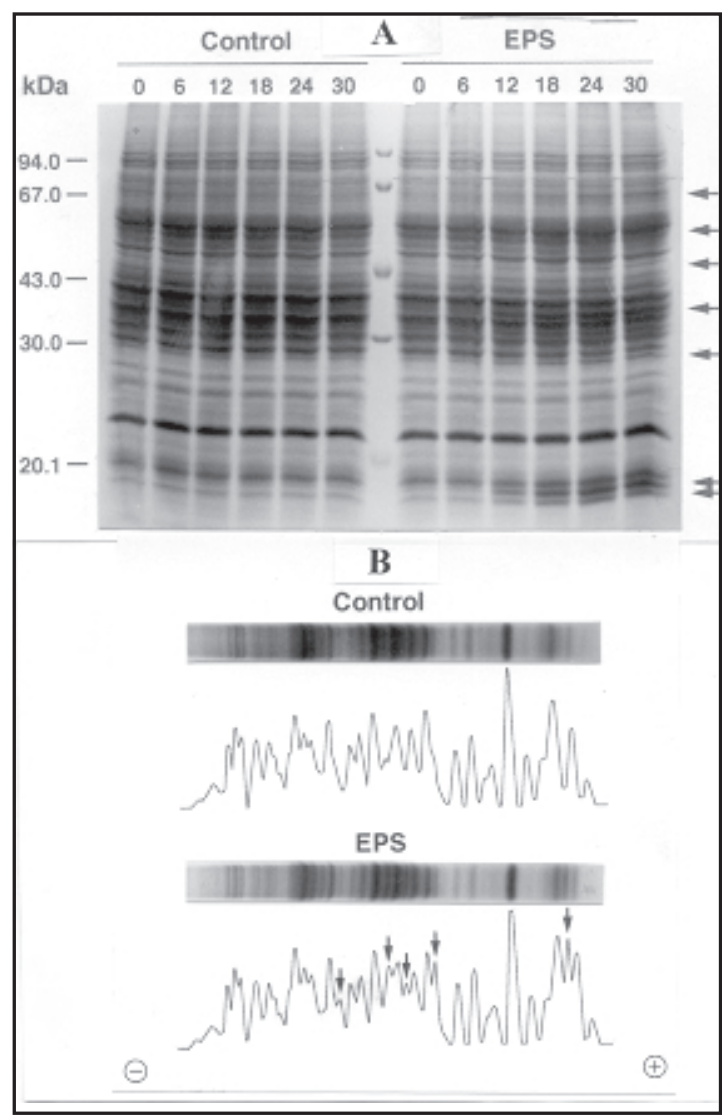

FIG. 4. Sodium dodecyl sulfate polyacrylamide gel electrophoresis (SDS-PAGE) of total protein extracted from cotton cell suspension cultures. (A) Time course of extracellular polysaccharides (EPS) treatment $(600 \mu \mathrm{g} / \mathrm{mL})$ is shown on the right lanes and of control cultures (mock-inoculated with fresh liquid medium only) are on the left. Numbers on the top indicate time of treatment in hours. (B) Densitometric scan of SDS-PAGE of total protein profile after 12 hours. Arrows indicate protein bands differentially accumulated by EPS treatment.

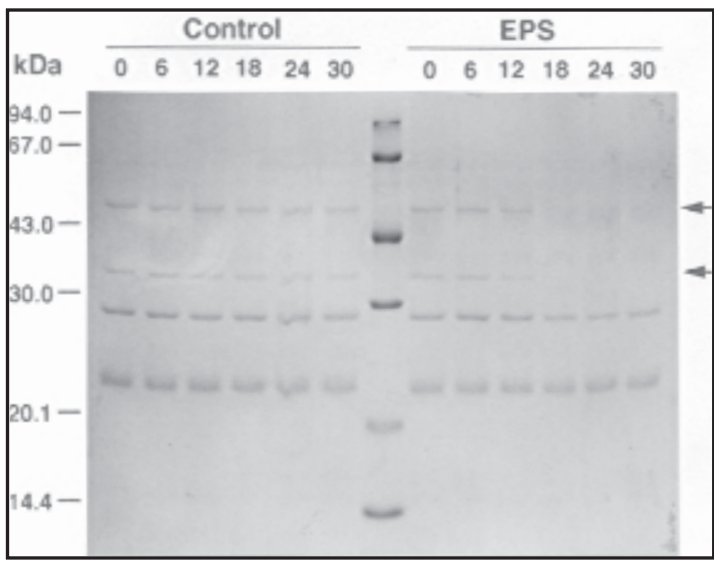

FIG. 5. SDS-PAGE of total protein present in the cell suspension culture medium. Number on the top of each lane indicates time of treatment in hours. Arrows indicate protein bands differentially accumulated in cultures treated with EPS $(600 \mu \mathrm{g} / \mathrm{mL})$.

tures was associated with hypersensitive reaction (Fig. 4). Although more detailed studies related to the functions of such proteins are needed, these data suggest a relationship between the differential accumulation of proteins and resistance of cotton cultivar 101-102B to bacterial blight.

The results demonstrate the possibility of using cotton cell suspension cultures in combination with bacterial EPS as an in vitro system for inducing the expression of cotton genes related to the hypersensitive reaction. Further investigations aiming to identify genes that may be differentially activated in cotton cells following EPS treatment would be worthwhile. Nevertheless, this system may also be useful for the overall understanding of molecular events in the incompatible interaction of cotton to $X$. campestris pv. malvacearum.

\section{CONCLUSIONS}

Recently, Liu et al. (1995) reported the accumulation of PR-proteins in cotton seedlings associated with resistance to Verticillium wilt. The results of this research showed that the differential accumulation of some proteins in EPS-treated cell suspension cul- 
2. Cell suspension cultures of cotton treated with extracellular polysaccharides (EPS) from an incompatible race of $X$. campestris pv. malvacearum reproduces the hypersensitive reaction observed in whole plant-pathogen interaction.

3. In this system, extracellular polysaccharides (EPS) from an incompatible race of $X$. campestris pv. malvacearum induces differential accumulation of proteins.

\section{ACKNOWLEDGEMENTS}

To Dr. Y.R. Mehta for critically reading the manuscript.

\section{REFERENCES}

ATKINSON, M.M. Molecular mechanisms of pathogen recognition by plants. Advances in Plant Pathology, San Diego, v.10, p.35-64, 1993.

AUSUBEL, F.M.; GLAZEBROOK, J.; GREENBERG, J.; MINDRINOS, M.; YU, G.L. Analysis of the Arabidopsis defense response to Pseudomonas pathogens. In: VERMA, D.P.S. (Ed.). Advances in molecular genetics of plant-microbe interactions. Dordrecht : Kluwer Academic, 1993. p.293-403.

BORKAR, S.G.; VERMA, J.P. Inhibition of susceptible water soaking and/or hypersensitive reaction in cotton by exopolysaccharide of avirulent Xanthomonas campestris pv. malvacearum. Folia Microbiologica, Prague, v.36, p.169-172, 1991.

CAMPBELL, M.M.; ELLIS, B.E. Fungal elicitor-mediated responses in pine cell cultures. 1. Induction of phenylpropanoid metabolism. Phytochemistry, Elmsford, v.31, p.737-742, 1992.

CHOWDHURY, H.D.; VERMA, J.P. Exopolysaccharide production by pathogenic and nonpathogenic bacteria associated with leaves of cotton. Indian Phytopathology, New Delhi, v.33, p.304-307, 1990.

DALKIN, K.; JORRIN, J.; DIXON, R.A. Stresses response in alfalfa (Medicago sativa L.). VII. Induction of defense related mRNAs in elicitor-treated cell suspension cultures. Physiological and Molecular Plant Pathology, London, v.37, p.293-307, 1990.

DANGL, J.; DENEBER, T.; GERWIN, M.; KIEDROWISK, S.; RITTER, C.; BENDAHMANE,
A.; LIENDGENS, H.; LEWALD, J. Genetic approaches to an understanding of specific resistance responses of Arabidopsis thaliana against phytopathogenic pseudomonads. In: VERMA, D.P.S. (Ed.). Advances in molecular genetics of plant-microbe interactions. Dordrecht : Kluwer Academic, 1993. p.405-415.

DIXON, R.A.; HARRISON, M.J. Activation, structure and organization of genes involved in microbial defense in plants. Advances in Genetics, San Diego, v.28, p.165-234, 1990.

DOW, J.M.; OSBOURN, A.E.; WILSON, T.J.G.; DANIELS, M.J. A locus determining pathogenicity of Xanthomonas campestris is involved in lipopolysaccharide biosynthesis. Molecular Plant Microbe Interactions, Saint Paul, v.8, p.768-777, 1995.

EBEL, J.; SCHIMIDT, W.E.; LOYAL, R. Phytoalexins synthesis in soybean cells: elicitor induction of phenylalanine ammonia-lyase and chalcone synthase mRNAs and correlation with phytoalexin accumulation. Archives of Biochemistry and Biophysics, San Diego, v.232, p.240-248, 1984.

EDWARDS, K.; CRAMER, C.L.; BOLWELL, G.P.; DIXON, R.A.; SCHUCH, W.; LAMB, C.J. Rapid transient induction of phenylalanine ammonia-lyase mRNA in elicitor treated bean cell. National Academy of Science of the United States of America Proceedings, Washington, v.82, p.6731-6735, 1985.

EL-BANOBY, F.E.; RUDOLPH, K. Induction of watersoaking in plant leaves by extracellular polysaccharides from pseudomonads and xanthomonads. Physiological Plant Pathology, London, v.15, p.341-349, 1979 .

FRITTENSKY, B.; RIGGLEMAN, R.C.; WAGONER, W.; HADWIGER, L.A. Gene expression in susceptible and disease-resistant interactions of peas induced with Fusarium solani pathogens and chitosan. Physiological Plant Pathology, London, v.27, p.15-18, 1985.

GOODMAN, R.N.; NOVACKY, A.J. The hypersensitive reaction in plants to pathogen. Saint Paul : American Phytopathological Society, 1994. 244p.

GRAHAM, T.L.; GRAHAM, M.Y. Cellular coordination of molecular responses in plant disease. Molecular Plant Microbe Interactions, Saint Paul, v.4, p.415422, 1991. 
JAKOBEK, J.L.; LINDGREN, P.B. Generalized induction of defense responses in bean is not correlated with the induction of the hypersensitive reaction. Plant Cell, Baltimore, v.5, p.49-56, 1993.

KAO, C.H.; BARLOW, E.; SEQUEIRA, L. Extracellular polysaccharide is required for wild- type virulence of Pseudomonas solanacearum. Journal of Bacteriology, Washington, v.174, p.1068-1071, 1992.

KEPPLER, L.D.; ATKINSON, M.M.; BAKER, C.J. Plasma membrane alteration during bacteria-induced hypersensitive reaction in tobacco suspension cells as monitored by intracellular accumulation of fluorescein. Physiological and Molecular Plant Pathology, London, v.2, p.209-219, 1988.

LAEMMLI, U.K. Cleavage of structural proteins during the assembly of the head of bacteriophage T4. Nature, London, v.227, p.680-685, 1970.

LANGE, B.M.; TROST, M.; HELLER, W.; LANGEBARTELS, C.; SANDERMANN, J.R.H. Elicitor-induced formation of free and cell-wall-bound stilbenes in cell suspension cultures of Scots pine (Pinus sylvestris L.). Planta, Berlin, v.194, p.143148, 1994.

LESNEY, M.S. Growth responses and lignin production in cell suspensions of Pinus elliottii 'elicited' by chitin, chitosan or mycelium of Cronartium quercum f.sp. fusiforme. Plant Cell, Tissue and Organ Culture, Dordrecht, v.19, p.23-31, 1989.

LI, H.F.; WHITE, R.F.; ANTONIW, J.F. The effect of virus inhibitor, NS-83, derived from plants, on virus infection and multiplication in tobacco. Journal of Phytopathology, Berlin, v.128, p.299-305, 1990.

LIU, R.J.; LI, H.; SHEN, C.Y.; CHIU, W.F. Detection of pathogenesis-related proteins in cotton plants. Physiological and Molecular Plant Pathology, London, v.47, p.357-363, 1995.

MILLS, D.R.; LEE, J.M. A simple and accurate method for determining wet and dry weight concentrations of plant cell suspension cultures using microcentrifuge tubes. Plant Cell Reports, Berlin, v.15, p.634-636, 1996.

MURASHIGE, T.; SKOOG, F. A revised medium for growth and bioassay with tobacco tissue cultures. Physiologia Plantarum, Copenhagen, v.15, p.473497, 1962.

NASSER, W.; TAPIA, M.; KAUFFMANN, S.; BURKARD, G. Identification and characterization of maize pathogenesis-related proteins, four maize proteins are chitinases. Plant Molecular Biology, Dordrecht, v.11, p.529-538, 1988.

PALVA, T.; HOLMSTROM, K.O.; HEINO, P.; PALVIO, E.T. Induction of plant defense response by exoenzyme of Erwinea carotovora subsp. Molecular Plant Microbe Interactions, Saint Paul, v.6, p.190196, 1993.

POPP, M.P.; MARK, M.S.; DAVIS, J.M. Defense responses elicited in pine cell suspension cultures. Plant Cell, Tissue and Organ Culture, Dordrecht, v.7, p.199-206, 1997.

WALKES, C.M.; O'GARRO, L.W. Role of extracellular polysaccharides from Xanthomonas campestris pv. vesicatoria in bacterial spot of pepper. Physiological and Molecular Plant Pathology, London, v.48, p.91-104, 1996.

WIDHOLM, J. The use of fluorescein diacetate and phenosafranine for determining viability of cultured plant cells. Stain Technology, Baltimore, v.47, p.189194, 1972.

WOJTASZEK, P.; TRETHOWAN, J.; BOLWELL, G.P. Specificity in the immobilization of cell wall proteins in response to different elicitor molecules in suspension-cultured cells of French bean (Phaseolus vulgaris L.). Plant Molecular Biology, Dordrecht, v.28, p.1075-1087, 1995. 